\title{
Galatians 5.11: Evidence of an Early Law-observant Mission by Paul?
}

\author{
DOUGLAS A. CAMPBELL \\ The Divinity School, Duke University, Box 90968, Durham, NC 27708-0968, USA. \\ email:dcampbell@div.duke.edu.
}

\begin{abstract}
Galatians 5.11 refers to Paul 'proclaiming circumcision'-a proposition that he is concerned to refute because he constructs two compact but powerful inferences designed to falsify it. One argues from present persecution, the other from the cross. Following a precise reconstruction of these it can be shown that the three main previous interpretations of the reference of Paul's 'proclamation of circumcision' are dubious, whether in terms of a blatantly false charge by opponents, a phase in Paul's pre-Christian Jewish life, or an occasional apostolic mission to Jews. A fourth, embarrassing reading is more likely, especially when other comparable missionary work is considered. Early on Paul proclaimed a fully law-observant gospel to pagans that included circumcision, but then later revised his praxis.
\end{abstract}

Keywords: Paul, Galatians 5.11, law-observant, law-free, mission, opponents, apostle

Galatians 5.11 is a difficult, contested, but potentially highly significant text that merits careful scrutiny. ${ }^{1}$ It will be discussed here in the following terms:

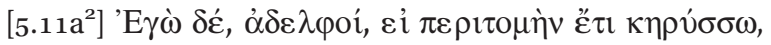

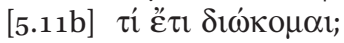

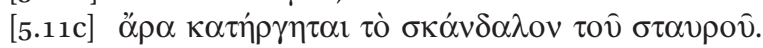

1 While I disagree with his reading, I remain grateful to Terence (Terry) L. Donaldson for first alerting me to the importance of this text. His discussions remain among the fullest and most insightful: cf. esp. his Paul and the Gentiles: Remapping the Apostle's Convictional World (Minneapolis: Fortress, 1997) esp. 277-83; summarized in 'Israelite, Convert, Apostle to the Gentiles: The Origin of Paul's Gentile Mission', The Road From Damascus: The Impact of Paul's Conversion on his Life, Thought, and Ministry (ed. R. N. Longenecker; Grand Rapids: Eerdmans, 1997) 62-84.

2 All biblical references in what follows are to Galatians unless otherwise indicated. 
At first glance, 5.11a suggests that Paul at some point 'preached circumcision', which would be a deeply interesting if not astonishing fact if it applied to his apostolic ministry. It is not surprising, however, that this reading has been widely marginalized in favor of other construals. Meanwhile, some exegetes simply despair of ever fully understanding Paul's pithy rejoinders. ${ }^{3}$ I suggest in what follows, however, that the verse's difficulties can be negotiated, and that the embarrassing 'apostolic' reading is the most likely construal of Paul's claims in 5.11a, and to some degree for just this reason.

\section{The Original Text}

As we turn to detailed investigation our first question concerns the text's original form since the Western tradition omits the first instance of है $\tau$, from $5.11 \mathrm{a} .{ }^{4}$ If this variant is original, the majority text could be explained as the eye of a scribe generating a doubling error by traveling forward along the line to the second हैं $\tau$ and including another instance earlier. But omissions are usually easier to explain than additions since scribes, paid by quota, tended to hurry and to compress. Moreover, it seems unlikely that this addition would then have influenced so many subsequent manuscripts in different major families, while our earliest MSS also include it. So the Western reading that omits the first हैं $\tau$ is almost certainly secondary. This variant might have been caused by a careless omission that reversed the foregoing error-a scribal eye jumping forward to the second है $\tau$ l and omitting the first, or simply getting confused during aural and/or mental repetition. Also possible, however, is the deliberate omission of an embarrassing word, which eliminates the obvious further problem that Paul now never preached circumcision. ('How could this be?!') Reconstructing textual variants is not a precise science, but the possibility of deliberate scribal omission on grounds of embarrassment will complement our later arguments nicely. ${ }^{5}$

In due course we will see that a majority reading of this text exists, along with two minority readings, but that these approaches all possess debilitating problems. So I will contend that another, less popular approach does solve these difficulties. Somewhat counter-intuitively, however, it will be clearest to consider one of the minority positions first.

3 H. D. Betz opines '[w]hat the Apostle has precisely in mind will in all likelihood always be hidden from our knowledge' (Galatians [Philadelphia: Fortress, 1979] 268).

4 D*, F, G, 0278., 6., 1739., 1881, pc a, b, vg ${ }^{\text {mss }}$; Ambrosiaster.

5 In this whole relation see Bart Ehrman, The Orthodox Corruption of Scripture: The Effect of Early Christological Controversies on the Text of the New Testament (New York: Oxford University, 1993); some of David C. Parker's remarks about the MS tradition of the gospels are also apposite in The Living Text of the Gospels (Cambridge: Cambridge University, 1997). 


\section{J. L. Martyn's Non-temporal Reading ${ }^{6}$}

Most construals of 5.11 grapple with the usual temporal sense of हैंt in terms of 'still' ('...if I still preach circumcision then...'). Martyn, however (partly in dependence on Mussner ${ }^{7}$ ), argues for a rather different translation, and if he is successful then all the biographical implications of the verse are eliminated at one fell swoop, not to mention its difficulties. But I am not convinced that he has made his case.

The NT uses the adverb है $\tau$ almost one hundred times, Paul using it fifteen or sixteen times. The most usual sense is one of continuation or extension, whether through time or space, some activity, or by way of analogy (e.g., extending inclusion within a group to 'yet/still one or two more'; cf. Matt 18.16), suggesting the translations 'still', 'yet', 'further', 'even', and occasionally 'additionally'. ${ }^{8}$ The best translation in all Paul's material, barring question-begging instances, is 'still'. ${ }^{9}$ However, it is possible that Paul is using one of its less common senses in 5.11. And Martyn has suggested the meaning 'additionally' for its occurrence in $5.11 \mathrm{a}^{10}$ (urging the same meaning for its occurrence in $1.10^{11}$ ). 'If I were on occasion advocating the circumcision of Gentile converts, the persecution of me...would cease'. ${ }^{12}$ But this is of course a paraphrase. A stricter translation would be: 'And brothers, if $I$ preach circumcision by way of addition, then why am I still being persecuted?' ${ }^{\prime 3}$

The broader implication of this reading, and its main strength, is the suggestion that a blatantly false claim is being made by Paul's opponents-that

6 J. L. Martyn, Galatians: A New Translation with Introduction and Commentary (London/ New York: Doubleday, 1997), esp. 475-7.

7 Franz Mussner, Der Galaterbrief (Freiburg/Basel/Vienna: Herder, 1974) 359.

8 Cf. BDAG: 400; LNSM 1:603 (59.75), 646 (67.128), 795 (89.135); 2:107; LSJ: 703.

9 See esp. Rom 3.7; 5.6 (2×), 8; 6.2; 9.19; 1 Cor 3.2, 3; 12.31; 15.17; 2 Cor 1.10; Gal 1.10; 5.11 (2x); Phil 1.9; cf. 2 Thess 2.5. A possible exception to my claim here, in addition to $5.11 \mathrm{a}$, is 1.10, which is considered further just below.

10 Even in its so-called 'logical' or 'argumentative' use the notion of extension is still in fact primary; cf. Rom 3.7; 5.6 (2×), 8. Mussner, drawing on Mayser, cites the papyrus PSI VI, 623/21 (cf. M. Norsa and G. Vitelli, Papiri Greci e Latini, vol. VI [Florence: Pubblicazioni della Società Italiana, 1920]) for an ostensible instance of ع̌ $\tau$ f functioning in an $\varepsilon \dot{\imath}$ construction additively and argumentatively (Der Galaterbrief, 359 n. 113), but the connotation of extension

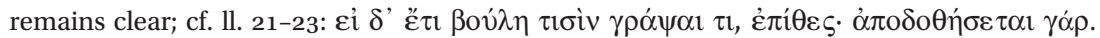

11 In fact, Paul seems to be querying aggressively here whether he pleases people by way of extension, or in addition to, pleasing God, going on to reject any such suggestion by limiting his allegiance, as a slave, to God alone. So although the English translation 'still' is a little awkward here, the basic notion of extension is clearly still (!) in play; Paul is denying the extension of his pleasing behavior to people beyond God.

12 Martyn, Galatians, 477.

13 The Greek contains an overt emphasis on the first person singular in 5.11a. 
elsewhere (i.e., outside Galatia), and only from time to time, ${ }^{14}$ Paul proclaims a gospel that includes a commitment to circumcision. ${ }^{15}$ This reading then removes the awkward implication from the usual translation that Paul may at some earlier point have preached circumcision himself. Paul's opponents could plausibly then have gone on to suggest that the apostle's original proclamation to the Galatians that omitted circumcision could fairly be supplemented by the Teachers' addition of the practice, while the apostle seems to have been an inconsistent and untrustworthy figure (cf. 1.10; 2.11-14).

Martyn's suggested translation is typically insightful. But it is unlikely.

(1) The second है $\tau 1$, in $5.11 \mathrm{~b}$, cannot be rendered 'additively'. How could Paul be persecuted 'in addition' or by way of extension except temporally, as something 'still' happening? So the adverb takes its usual sense in $5.11 \mathrm{~b}$ of 'still'. And in such a short, pithy set of arguments it seems more likely that Paul would hold the meaning of the adverb constant than that he would shift the meaning of ع̈ $\tau$ in successive clauses. (Martyn concedes that this is a problem. ${ }^{16}$ )

(2) The word order supports an adverbial interpretation, है $\tau$ invariably modifying the material that follows it elsewhere in Paul (and almost always in the $\mathrm{NT}^{17}$ ), here 'preaching'. ${ }^{18}$ Hence, हैं $\tau$ must be functioning out of sequence for Martyn's construal of 5.11a to work, which is not impossible but neither is it ideal.

(3) Martyn's reading views the charge behind 5.11a as an outright falsehood, a sheer fabrication, at which point it seems puzzling that Paul does not simply deny it. Paul frequently repudiates lies under oath in his letters (cf. 2 Cor 11.31), and even does so earlier on in Galatians (cf. 1.19-20). Moreover, it seems an odd charge to fabricate. (Martyn admits to being puzzled by this. ${ }^{19}$ ) If it is blatantly untrue then it would seem to risk rebounding onto the heads of its fabricators quite directly; they are liars.

These counter-arguments do not amount to a definitive repudiation of Martyn's suggestion, but if we can formulate a less problematic reading based on more typical usage then it should be preferred.

14 Martyn's translation adds this to the Greek but it is a necessary inference of the scenario since Paul is clearly not preaching circumcision at Galatia.

15 Mussner notes the discussion of this 'Verleumdungshypothese' in German scholarship by Sieffert, Zahn, and Oepke. He himself is not convinced by it, suggesting instead-somewhat opaquely - a blatant false hypothetical statement by Paul (Der Galaterbrief, esp. 359 and n. 112).

16 Martyn, Galatians, 476.

17 Strongly semitized Greek is an exception to this practice, but is not apparent here or more widely in Paul: cf. Heb 8.12, modifying Jer 31.34; and Rev 3.12; 7.16, modifying Isa 49.10; 12.8; $18.21-23 ; 20.3 ; 21.1,4 ; 22.3,5,11$; ع̌ $\tau 1$ in these instances rendering

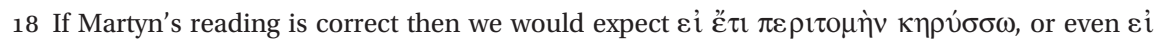

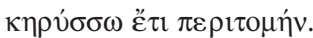

19 Martyn, Galatians, 477. 
As we turn to consider the remaining interpretative options I suggest that we understand the syntax as follows.

5.11 is a complex first class conditional argument in which two apodoses are supposed to falsify in coordination the ostensible facticity of a single protasis. ${ }^{20}$ We are led to this syntactical judgment because-as will become apparent shortly-it is difficult to supply a coherent line of argument to the text if the claim of $5.11 \mathrm{c}$ is read directly on from $5.11 \mathrm{~b}$, and yet both $5.11 \mathrm{~b}$ and $5.11 \mathrm{c}$ function well as attempted refutations of 5.11a. (It is also impossible to assign $5.11 \mathrm{~b}$ a parenthetical function.) So the most plausible reconstruction views $5.11 \mathrm{~b}$ and $5.11 \mathrm{c}$ as functioning together, in coordination, to refute the charge of $5.11 \mathrm{a}^{21}$ This leaves us with two related but distinguishable arguments-5.11a-b and 5.11a-c-that can be traced through in more detail. Both are highly compressed but powerful contentions.

\section{The Argument of $5.11 \mathrm{a}-\mathrm{b}$}

In $5.11 \mathrm{~b}$ Paul suggests in a conditional argument that he is not 'still' preaching circumcision (so 5.11a) because he is 'still' being persecuted. The apodosis therefore supplies a narrative and biographical contention. Moreover, the overarching refutation of 5.11 a seems to rest on a true claim. (The argument in 5.11c will work rather differently.) But we need to supply quite a bit of additional information to Paul's argument in order to grasp it fully.

For Paul's argument in 5.11a-b to hold, his gospel and its revolutionary stance on circumcision must have elicited at least some of his previous persecutions, and this information must have been clear to his Galatian auditors. (Note that we are not considering here why a circumcision-free gospel generates such opposition, but just the brute fact of it.) That is, the Galatians must know that Paul's circumcision-free gospel and any persecution of him exist in a directly correlative relationship. And the converse must also hold: that when Paul's—or anyone else's -gospel endorses circumcision it does not seem to entail persecution. Moreover,

20 So, as Daniel Wallace suggests, the first class form does indicate the holding of something to be true for the sake of argument: see The Basics of New Testament Syntax: An Intermediate Greek Grammar (Grand Rapids: Zondervan, 2000), esp. 311-12. Mussner advocates this construal of the syntax in 5.11 (Der Galaterbrief, 360).

21 Alternatively, a repeated protasis could have been elided as clumsily repetitive, although this amounts to the same thing. (It might nevertheless clarify things considerably if it is supplied in translation.)

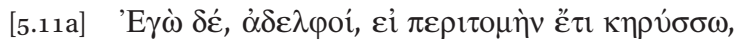

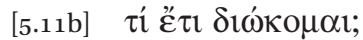

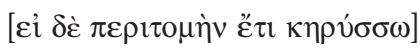

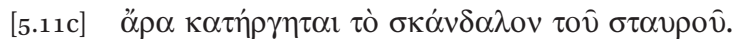


these two associations - of circumcision-free preaching and persecution, and procircumcision preaching and no persecution-must be mutually exclusive. Put more formally then: A entails $\mathrm{Y}$, and a converse situation, B, entails Z; A-Y and $\mathrm{B}-\mathrm{Z}$ are mutually exclusive. Paul states in $5.11 \mathrm{~b}$ explicitly that $\mathrm{Z}$ is present (persecution), therefore A is not the case (an inoffensive pro-circumcision gospel; so 5.11a); rather, B is (which is implict; Paul continues to preach a circumcisionfree gospel). So here the truth of ' $\mathrm{Z}$ ', supplied specifically in $5.11 \mathrm{~b}$, refutes the ostensible truth of ' $A$ ', stated in 5.11a.

It will follow then from the Galatians' knowledge of these largely biographical equations that any roughly current persecution of Paul—so 5.11b-suggests fairly directly that any purported abandonment by him of a circumcision-free gospel in favour of one endorsing circumcision must be false, thereby negating 5.11a. Without this narrative, however, Paul's argument does not really make sense. That is, it is not merely invalid but incoherent. ${ }^{22}$ But it is likely that the Galatians were aware of this correlation.

Scholars have tended to debate in the past whether the persecution evident in relation to Paul came from Jewish Christians in particular or from outside the early church from Jewish groups. ${ }^{23}$ Certainly, however, there is sufficient evidence in Galatians alone to posit its existence and thereby a narrative in which Paul's circumcision-free gospel has been opposed strongly, at times to the point of persecution. ${ }^{24}$ And if Paul had recently traveled through Galatia in person, that

22 It is not clear how suffering some sort of generic persecution would help to refute the accusation of 5.11a-that Paul has preached a gospel endorsing circumcision elsewhere. Only persecution of Paul in the past for this very thing allows the argument to function plausibly. Martyn grasps this point-and the entire argument at this stage-with complete clarity (Galatians, 477).

23 A classic study of this phenomenon is Robert Jewett, 'The Agitators and the Galatian Congregation', NTS 17 (1971) 198-212; see also, more recently, John Muddiman, 'An Anatomy of Galatians', Crossing the Boundaries: Essays in Biblical Interpretation in Honor of Michael D. Goulder (ed. Stanley E. Porter et al.; Leiden: Brill, 1994) 257-70. However, it is both unnecessary and unwise to try to draw strict boundaries between the different networks involved-as, to a certain extent, Jewett and Muddiman do-while opposition to Paul may have shifted across putative boundaries in any case. On the boundary issues see especially the classic analysis of Mary Douglas, Purity and Danger: An Analysis of Concepts of Purity and Taboo (London: Routledge \& Kegan Paul, 1970); updated, and related to Paul, in David G. Horrell, Solidarity and Difference: A Contemporary Reading of Paul's Ethics (London: T. \& T. Clark [Continuum], 2005).

24 Various hints in the data point towards some persecution of Paul surrounding the Jerusalem conference, which may well have arisen from Jewish groups 'outside' the early church; see esp. 2.12; 4.29; and 6.12. (Paul speaks of his own persecution of the church in 1.13, 23, thereby confirming the activity's aggression.) An important study of 4.29 is Susan G. Eastman, "Cast Out the Slave Woman and her Son": The Dynamics of Exclusion and Inclusion in Galatians 4.30', JSNT 28 (2006) 309-36. Some of the struggles noted in 2 Cor 11.23-25 belong here, most notably, instances of extreme synagogual discipline (v. 24); cf. 
is, shortly before writing the letter, as both 1 Cor 16.1 and Gal 4.13 might suggest, then he has even personally recounted to the Galatians a story of his recent troubles in Jerusalem precisely over his circumcision-free approach to mission. ${ }^{25}$ So the correlation implicit in Paul's argument in 5.11a-b seems plausible. He has been persecuted in the past for his circumcision-free gospel; these two phenomena exist in a direct relationship. Moreover, the converse also holds. Others do not seem to have been persecuted for preaching a gospel that includes circumcision (cf. esp. 6.12), a trajectory that included Paul at some stage. Hence the refutation of $5.11 \mathrm{a}$ by $5.11 \mathrm{~b}$ holds. If Paul is still preaching circumcision then he clearly would not be suffering such persecution. But he is suffering such persecution so equally clearly he is not still preaching an inoffensive gospel that affirms circumcision but its converse. And we have now explained Paul's second use of the word हैं $\tau$ in $5.11 \mathrm{~b}$.

At first glance this word does not seem necessary in argumentative terms. Paul only needs instances of relatively recent and appropriate persecution to suggest that he is not therefore 'still' preaching an inoffensive gospel of circumcision. And these could well have been drawn (and probably were) from events in Jerusalem and Judea-the pressures he and Barnabas have just suffered there. The second use of the adverb हैं $\iota$ in 5.11 in a temporal sense is not then really necessary. 'If I am being persecuted, then I am not still preaching circumcision' would suffice. But the use of this word a second time achieves at least one, and possibly two, things.

First, it has a noticeable rhetorical contribution to Paul's argument. Because it resumes the 'still' of the protasis in 5.11a it is this particular notion in 5.11a that is refuted by the sharp riposte in $5.11 \mathrm{~b}$. This emphasis is clearest in reverse. 'That I am still being persecuted suggests that I am not still preaching circumcision'. And this is a highly revealing emphasis for the Pauline biographer since it points explicitly to the concession lying within Paul's argument that he did in fact at some stage 'preach circumcision'. The apostle even seems to emphasize here that he is not 'still' doing this, thereby conceding that once admittedly he did. He is just denying-emphatically—that he is doing this now.

Martyn adds a second interpretative layer. ${ }^{26} \mathrm{He}$ observes that the second instance of ह̌兀ı pulls Paul's narrative of persecution right into the present,

also, on one probably earlier occasion, a stoning (v. 25; cf. Acts 14.19). The hotly contested 1 Thess 2.14-16 integrates exactly with this scenario.

25 The commentators generally do not place much weight on $\tau$ ò $\pi \rho$ ó $\varepsilon \rho o v$ in 4.13 ; cf. e.g. Longenecker, Galatians (Dallas: Word, 1990) 190. But the translation of 'the former [of two visits]' does align exactly with this scenario.

26 It could be asked if we should prefer one of these two explanations of 'still' - the argumentative or the rhetorical. Strictly speaking, Paul's usage only needs one. But a decision here 
thereby neatly invoking Paul's present difficulties at Galatia as a further instance of his history of persecution by his opponents-opponents, that is, of his apostolic ministry to the pagans in liberative terms. (Paul could not of course have included a narrative of his difficulties in Galatia to the Galatians if he had passed through recently; they would not yet have occurred.) The word suggests that these situations all belong together in one trajectory. The Galatians' own situation therefore confirms Paul's refutation of the shocking charge implicit in 5.11a-and they are drawn into his side of the battle: 'If I were on occasion advocating circumcision of Gentile converts, the persecution of me that was commenced by the False Brothers at the Jerusalem meeting-and that continues to this day in the activity of the Teachers-would cease. In fact, as you yourselves know very well, that persecution has by no means come to an end...' ${ }^{27}$

\section{The Argument of 5.1 1a-c}

A second conditional argument is effected by 5.11c that begins with the inferential particle öp $\alpha .^{28}$ But whereas $5.11 \mathrm{~b}$ introduced a biographical contention, 5.11c makes a more overtly theological claim in relation to the cross.

ultimately seems unnecessary. We have no strong grounds for preferring one over the other, or for insisting on a single explanation when both seem compatible with one another.

27 Martyn, Galatians, 477, emphases added. Admittedly a link between the conference in Jerusalem (2.1-10) and the troubles in Galatia needs to hold for this further connotation to be present. But the hostility apparent around and at the Jerusalem conference could plausibly have extended through to Paul's present struggle in Galatia. One does not get the sense that the 'sneaking' and 'enslaving' 'false brothers' of 2.4 would have left the Jerusalem conference content. Moreover, while not necessarily persecuting the Galatians, Paul's opponents there do seem to be hostile to Paul himself, who may well have been anathematized (cf. 1.8-9; 5.10 and 12), and be facing life-threatening battles in a Roman court (cf. Phil 1.12-21). If the Teachers are prosecuting Paul to achieve what would have been in effect judicial homicide then Martyn is certainly entitled to link the Galatian struggle back to the Judean conflict. Acts also attests multiply to Paul's battles in court: cf. 18.12-17; 21.27-29; 22.21-23; and 23.12-15. (Bradley R. Trick offers a countervailing opinion and extensive annotation in 'Sons, Seed, and Children of Promise in Galatians: Discerning the Coherence in Paul's Model of Abrahamic Descent' [PhD diss., Duke University, 2010], http://dukespace.lib.duke.edu/dspace/bitstream/10161/ 2271/1/ D_Trick_Bradley_a_201005.pdf, esp. 504 n. 223 and 506 n. 227.)

28 See 1 Cor 15.18 for a similar use of öp $\alpha$ continuing an apodosis. BDAG defines it, in meaning 2a, as an expression of result- 'then, as a result', with a 'suggestion of emphasis' (127). See also 1 Cor 15.14; 2 Cor 5.14; Gal 2.21; and 3.29. Betz (followed by Longenecker: cf. Galatians, 233) suggests that the particle signals the conclusion of the entire sub-section, and not just the sentence (Galatians, 269) (cf. 2.21; 3.29; 6.10). But this is unlikely. 5.11 does not conclude a sub-section; it is a brief substantive aside in the midst of a short polemic by Paul against his opponents at Galatia. 
And whereas $5.11 \mathrm{~b}$ used a true claim to refute the ostensible truth of the protasis, assuming that the associations of the two claims were mutually exclusive, 5.11c uses a false, and even absurd, claim to indicate the falsity of 5.11a. So here the two claims are correlative, not mutually exclusive, and the obvious falsity of the second proves the falsity of the first. (I suspect that it is Paul's shift between these two different types of argument, coupled with their compressed, allusive developments, that has led to most of the interpretative difficulties surrounding Gal 5.11 in the past.) Hence the argument of 5.11a-c fills out a lacuna in the previous argument and in doing so fashions a brief but effective rejoinder.

We need first to recall the two correlations present in the argument of 5.11a-b that are doubtless still resonating when $5.11 \mathrm{c}$ is read: preaching a pro-circumcision gospel is inoffensive, but preaching a circumcision-free gospel is offensive. Indeed, some are so offended by it that on occasion they persecute its advocates. In the light of these assumptions Paul now runs a further argument:

(1) The cross of Christ is a shameful event-a $\sigma \kappa \alpha \dot{\alpha} \delta \alpha \lambda \sigma \nu-a n d$ hence is offensive. $^{29}$

(2) The cross of Christ cannot, however, (obviously!) be nullified in this sense (at least without massive reinterpretation and long cultural reorientation). The cross remains irreducibly offensive.

(3) And Paul still preaches-and even embodies-the cross and its obviously offensive implications (cf. 3.1; 4.13, 14; 6.17). Far from obscuring this dimension, he glories in it!

(4) Paul has not therefore abandoned his offensive gospel.

29 The cross is a significant theme in Galatians: cf. also 6.12 and 14, and the cognate verb in 2.19; 3.1; 5.24; and 6.14. Cf. esp. K. M. Coleman's classic analysis of crucifixion, 'Fatal Charades: Roman Executions Staged As Mythological Enactments', JRS 80 (1990) 44-75; amplified in relation to the NT by Joel Marcus, 'Crucifixion as Parodic Exaltation', JBL 125 (2006) 73-87. Interpreters can supply a great deal of information at this point, filling out Paul's reference to the 'scandal' or 'stumbling-block' of the cross with a putative theologia crucis (cf. H. Schlier, Der Brief an die Galater [Göttingen: Vandenhoeck \& Ruprecht, 1oth ed. 1971 (1949)] 173; Mussner, Der Galaterbrief, 359-63; F. F. Bruce, The Epistle to the Galatians: A Commentary on the Greek Text [Grand Rapids: Eerdmans, 1982] 238). But it is important to avoid managing Paul's argument at this point by supplying extensive unstated material. We do not need to know the exact content of the cross's scandal for Paul in order to grasp his argument here-and perhaps fortunately. Paul's specific deployments of this powerful discourse shift subtly across different settings; cf. Rom 9.33 (drawing on Isa 8.14 and 28.16, and for more details here see J. Ross Wagner, Heralds of the Good News: Israel and Paul in Concert in the Letter to the Romans [Leiden/Boston: Brill, 2002] 126-42, 55-7); 11.9; 14.13; 16.17; 1 Cor 1.23; 8.13; and 11.29. A powerful modern articulation of the intrinsic offensiveness of the grace of the cross is Karl Barth, Church Dogmatics, IV/ 1: The Doctrine of Reconciliation (trans. G. W. Bromiley; Edinburgh: T. \& T. Clark [Continuum], 2004 [1956]), esp. § 60, 'The Pride and Fall of Man', 358-513. 
(5) By implication, however, he still preaches an offensive gospel in the sense of a gospel free of circumcision (that is, for male pagan converts). ${ }^{30}$

(6) It follows from this that Paul has abandoned his inoffensive gospel of circumcision-so 5.11a.

(7) Note that if he has not, then the converse would apply-that he has abandoned the offensive cross, which is self-evidently not the case (see 2 and 3 above)-so 5.11c.

Paul's specific reasoning in 5.11a-c runs more formally, if A is true (an inoffensive pro-circumcision gospel) then $\mathrm{F}$ would also be true (an inoffensive cross) which we understand is the case from a chain of implicit connected claims, B through E-but F is obviously false (a cross emptied of offence) therefore A is false as well (that Paul preaches an inoffensive pro-circumcision gospel). And it seems that the exact meaning and force of all of Paul's contentions in 5.11 have now been settled-a double refutation of the truth of the claim that Paul 'still preaches [a gospel including] circumcision'. This is denied, on two counts. But we have yet to determine exactly when Paul proclaimed circumcision.

\section{Identifying when Paul Preached Circumcision}

We noted earlier that a majority opinion is apparent in the literature, followed by two minority suggestions, and the view that will ultimately be urged here. This yields four main options. (Other more idiosyncratic views with obvious weaknesses will not be treated in detail. ${ }^{31}$ )

30 Paul's opponents could have disputed the legitimacy of the critical argumentative transfer of offence here from claim two through to claim five-i.e., from the cross and preaching its offence to Paul's offensive circumcision-free preaching-arguing that these two 'offences' were not commensurate therefore Paul's case rests on rhetorical sleight of hand at a key moment. (One can preach an offensive cross without necessarily going on to offend in the matter of circumcision as well.) However, Paul doubtless would have argued that the two offences were intrinsically connected and the rest of the letter really proves this by connecting the cross of Christ necessarily with the proclamation of a gospel beyond circumcision (cf. esp. 6.14-15). His brief argument here is therefore not strictly necessary, although it still has force.

31 Peter Richardson (Israel in the Apostolic Church [Cambridge: Cambridge University, 1969]) suggests in passing that the reference might be to Paul's own circumcision, but this doesn't explain (i.a.) the reference to preaching. He notes further a suggestion by D. W. B. Robinson ('The Circumcision of Titus, and Paul's "Liberty"', ABR 12 [1964] 24-42) that for Paul to circumcise occasionally was 'a legitimate exercise of Paul's liberty' (Israel in the Apostolic Church, 90 and 92 n. 6). But Paul's intransigent defence of pagan freedom from circumcision is difficult to reconcile with such overtly flexible behaviour. Furthermore, if this was the case then we would expect Paul to counter with just this argument, in terms of freedom. Mussner suggests that the statement is simply of 'selbstverständlich irrealen Sinn' (Der Galaterbrief, 358), but this leaves us wondering why Paul has caused such trouble for himself. Peder Borgen's suggestion is likewise brilliant but 
(1) 5.11a refers to preaching activity by Paul before his call;

(2) 5.11a refers to missionary work to Jews by Paul after his call;

(3) 5.11a refers to an early phase in Paul's missionary work to pagans, after his call, when he did expect his male converts to be circumcised (a phase that has now passed); and

(4) 5.11a utilizes a non-temporal meaning of है $\tau$ and is simply a fabricated charge-that Paul occasionally preaches circumcision, i.e., when it suits him (so Martyn).

But the fourth reading has already been challenged so only three remain to be discussed in detail.

\subsection{A pre-Christian Mission by Paul?}

Perhaps 5.11a speaks of a mission on behalf of Judaism by Paul before he was called to the apostolate, a position well-represented by Terence L. Donaldson but dating back much earlier in the modern interpretative tradition, and really dominating it. ${ }^{32}$ However, this reading suffers initially from the increasingly

unhelpful: see 'Paul Preaches Circumcision and Pleases Men', Paul and Paulinism: Essays in Honour of C. K. Barrett (ed. M. Hooker and S. G. Wilson; London: SPCK, 1982) 37-46. He argues, correctly, that a non-literal, spiritual interpretation of circumcision was circulating in Judaism in Paul's day, and is even apparent in the apostle's writings at certain points (cf. my The Deliverance of God [Grand Rapids: Eerdmans, 2009] 559-71). But that Paul actually needs to refute the asseveration of preaching circumcision caustically in 5.11 indicates then that it cannot refer to an acceptable element within his own preaching. Indeed, if spiritual circumcision was at issue he could simply have denied the extension of circumcision from the spiritual to the fleshly dimension, making a distinction he pursues energetically in many other places in his letters (cf. Rom 2.29; Gal 5.16-6.6; cf. also Col 2.11-13). But this is nowhere apparent in his argument here. Consequently, various scholars have been right to reject this approach to 5.11a: so Martyn, Galatians, 476 n. 30, supported i.a. by Dunn and Barclay. James D. G. Dunn's The Epistle to the Galatians (London: A. \& C. Black, 1993) has a useful survey on pp. 278-80.

32 See Donaldson, Paul and the Gentiles, esp. 270-1, 77-83, with like-minded scholars listed in n. 21 on p. 366: Ernst Barnikol, Die vorchristliche und frühchristliche Zeit des Paulus-nach sein geschichtlichen und geographischen Selbstzeugnissen im Galaterbrief (Kiel: Walter G. Mühlau, 1929) 18-24; Rudolf Bultmann, Existence and Faith: Shorter Writings of Rudolf Bultmann (trans. Schubert M. Ogden; New York: Meridian, 1961) 113; Douglas R. A. Hare, The Theme of Jewish Persecution of Christians in the Gospel According to St Matthew (Cambridge: Cambridge University, 1967) 12; Gunther Bornkamm, Paul (trans. D. M. G. Stalker; London/New York: Harper \& Row, 1971 [1969]) 12, 19; H. J. Schoeps, Paul: The Theology of the Apostle in the Light of Jewish Religious History (trans. H. Knight; Philadelphia: Westminster, 1961 [1959]) 219; H. Hübner, Law in Paul's Thought (trans. James C. G. Grieg; Edinburgh: T. \& T. Clark, 1984) 108-perhaps; Lloyd Gaston, 'Paul and the Torah', Antisemitism and the Foundations of Christianity (ed. Alan Davies; New York/ Toronto: Paulist, 1979) 48-71, esp. 61-2 and n. 55; Bruce, The Epistle to the Galatians, 236; 
apparent flaw that there is little evidence of overt missionary work by Jews before the time of the early church, so it needs to be reformulated. ${ }^{33}$ Rather more likely then is the sense that 5.11a refers to a vigorous 'proclaiming' of circumcision (and presumably of related matters in the Torah) by Paul in some teaching capacity within the synagogue or some similar forum as suggested by Acts 15.21, perhaps along with Rom 2.21. And this is a possible, although distinctly minority,

and P. Lapide (with Peter Stuhlmacher), Paul Rabbi and Apostle (trans. L. W. Denef; Minneapolis: Augsburg, 1984) 68. Dunn, The Epistle to the Galatians, 278, lists in addition, Ernest de Witt Burton, A Critical and Exegetical Commentary on the Epistle to the Galatians (Edinburgh: T. \& T. Clark, 1920) 286; and Longenecker, Galatians, 233; to whom we can add George S. Duncan, The Epistle of Paul to the Galatians (London: Hodder \& Stoughton, 1966) 160; James H. Ropes, The Singular Problem of the Epistle to the Galatians (London: Oxford University, 1929) 15, 39; Ronald Y. K. Fung, The Epistle to the Galatians (Grand Rapids: Eerdmans, 1988) 239; and Ben Witherington, Grace in Galatia: A Commentary on St Paul's Letter to the Galatians (Grand Rapids: Eerdmans, 1998) 373. Jürgen Becker, Paul, Apostle to the Gentiles (trans. O. C. Dean Jr; Louisville, KY: Westminster John Knox, 1993 [1989]) 39-40, notes the view but demurs.

33 This realization has broken upon Pauline studies since the early 1990s. At this point I am persuaded particularly by Shaye J. D. Cohen, The Beginnings of Jewishness: Boundaries, Varieties, Uncertainties (London/Los Angeles/Berkeley: University of California, 1999), supported in general terms on the nature of conversion by Rodney Stark, The Rise of Christianity: A Sociologist Reconsiders History (Princeton: Princeton University, 1996). The origins of the modern debate lie in Scot McKnight, A Light among the Gentiles: Jewish Missionary Activity in the Second Temple Period (Minneapolis: Fortress, 1991); and Martin Goodman, Mission and Conversion: Proselytizing in the Religious History of the Roman Empire (Oxford: Clarendon, 1994). Especially convincing in addition are James Carleton Paget, 'Jewish Proselytism at the Time of Christian Origins: Chimera or Reality?', JSNT 18 (1996) 65-103 and Reidar Hvalvik, The Struggle for Scripture and Covenant: The Purpose of the Epistle of Barnabas and Jewish-Christian Competition in the Second Century (WUNT 2/82; Tübingen: Mohr Siebeck, 1996) 213-321. A much-noted recent marker is Daniel Boyarin, Border Lines: The Partition of Judaeo-Christianity (Philadelphia: University of Pennsylvania, 2004). Recently Michael Bird, in a useful primer on the issue, has judged that 'although proselytes to Judaism were made in significant numbers, there is no evidence for concerted, organized, or regular efforts to recruit Gentiles to Judaism via the process of proselytizing. Conversion to Judaism was a difficult affair, and was usually done at the initiative of the Gentile' (Crossing Over Land and Sea: Jewish Missionary Activity in the Second Temple Period [Peabody, MA: Hendrickson, 2010] 13). Insofar as we can trust this generalization then we can concludewith due caution-that it is difficult to conceive of Paul preaching or proclaiming 'circumcision' to pagans in any intentional missionary sense before his call ca. 30 CE. The theological dimension to early Christian mission is captured elegantly by C. Kavin Rowe in World Upside Down: Reading Acts in the Graeco-Roman Age (Oxford: Oxford University, 2009) 116-26. (My thanks to Joel Marcus for his assistance with this material and debate.) 
construal of $\kappa \eta \rho v \sigma \sigma \omega .{ }^{34}$ However, this somewhat domesticated interpretation has one principal difficulty-of rhetorical opacity.

It is difficult to reconstruct a meaningful argumentative (i.e., rhetorical) function for 5.11a in these terms. Understood as a reference to pre-call activity, on the one hand, Paul's critics would seem to gain little if anything by introducing it into discussion. And neither would Paul. On the other hand, Paul would not really need to refute it, and certainly not in these terms. So in all respects the argumentative function of the pre-call view is problematic. In a little more detail:

It is next to impossible to explain the presence of this assertion in the Galatian situation if it refers to pre-call activity on Paul's part. Paul had no need to raise this activity himself (that is, other than in the contextually irrelevant terms of reversal that we will discuss momentarily). It seems almost certain then that his opponents have raised this matter ${ }^{35}$ as part of their counter-biography. ${ }^{36}$ But it is not especially damaging to charge the apostle to the pagans with proclaming Moses-and even proselytizing Jews, if this activity is granted-before he was called to Christ! Indeed, this seems singularly otiose. Moreover, easy refutations of any such suggestion lie just to hand that for some reason are not deployed.

34 In Paul cf. Rom 2.21; 10.8, 14, 15; 1 Cor 1.23; 9.27; 15.11, 12; 2 Cor 1.19; 4.5; 11.4 (2x); Gal 2.2; 5.11; Phil 1.15; cf. also Col 1.23. This language in Paul is almost invariably (and arguably invariably) 'apostolic', that is to say, a reference to preaching of the gospel of Christ in some sense. A standard background treatment of $\kappa \eta \rho v \sigma \sigma \omega$ can be found in G. Friedrich, ' $ү \hat{\rho} v \xi \kappa . \tau . \lambda$. ',

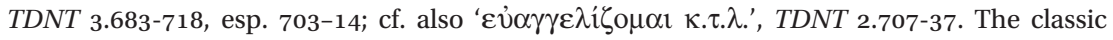

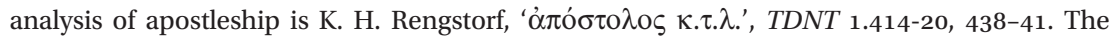
possible counter-instances to an apostolic reference of $\kappa \eta \rho v ́ \sigma \sigma \omega$ are Rom 2.21; Phil 1.15; and, elsewhere in the NT, Matt 10.27; Mark 1.45; 7.36; perhaps Acts 10.37 and 13.24; 15.21; and Rev 5.2. I (cf. Deliverance of God, esp. 495-600), supported by Martyn (cf. Galatians, passim), would not concede the Pauline references here to non-apostolic usage (i.e., we would refer them to false apostles), but the other NT instances remain exceptional. And these scattered non-apostolic instances undermine the use of 'apostolicity' as an argument against a pre-call reference by 5.11a (i.e, that this text necessarily has an apostolic, hence post-call, 'Christian' resonance in its terminology). The best that can be inferred on the basis of these data is that the language is preponderantly apostolic for Paul and hence inclines interpretation toward some 'Christian' usage in $5.11 \mathrm{a}$, placing the burden of proof on other readings. But clearly this argument is not decisive.

35 That this charge stems from Paul's opponents in Galatia seems almost certain. It interrupts his polemical characterizations of their behavior-as behaving in an unsportsmanlike manner (v. 7b), as troublers destined for judgment (v. 1ob), and as benefiting from emasculation (v. 12)!

36 That a counter-biography is in play in Galatians to some degree is an enduring insight derived originally from F. C. Baur, Paul, the Apostle of Jesus Christ, his Life and Works, his Epistles and Teachings: A Contribution to a Critical History of Primitive Christianity (London: Williams \& Norgate, 2nd ed. 2003 [1845; 1873-75]) but, suitably modified, still applicable; cf. esp. Gal 1.1-2, and 11. John Barclay's cautions should, however, be noted here: 'Mirror-reading a Polemical Letter: Galatians as a Test Case', JSNT 31 (1987) 73-93. 
Paul's usual strategy in relation to his background is reversal (see esp. Gal 1.13-17 and Phil 3.4-10). He uses zealous but misguided activity prior to his call as evidence of the divine nature of that call since it cut diametrically across those previous activities. ${ }^{37}$ And that strategy would clearly work here as well. So it is puzzling that he does not make this move simply stating that in the light of Christ his prior teaching zeal—or his missionary ardour-has been abandoned: 'Even as I used to proclaim circumcision, God revealed his son to me, and now I preach him!' But he does not. (Indeed, he does not even mention any such missionary activity in his autobiographical texts.) But Paul could in any case just reply

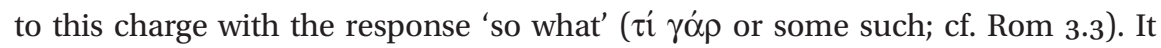
signifies nothing in relation to his current Christian activities. By this point in the letter the misguided nature of his pre-call life is old news (cf. 1.13-14). Moreover, in view of these effective and reasonably straightforward possibilities there is no need for Paul to make the weaker and more complex inferential and concessive arguments that he does make in $5.11 \mathrm{~b}$ and $\mathrm{c}$-the arguments associated precisely with his use of the word 'still' that have so often baffled his later readers.

In short, the pre-call reading cannot explain what this text is doing in the letter-why the charge is present in the text at all, why it is weighty enough to call for argued rejection, and why it is rejected in the subtle, convoluted, and concessive fashion that it is. Hence it seems that if another reading can deal with these exigencies it will enjoy a significant advantage over the pre-call reference.

\subsection{A Post-call Mission to Jews?}

Partly in view of these difficulties Francis Watson has argued cleverly that Paul is referring in 5.11a to previous missionary work when he was first called to be an apostle, but to Jews. ${ }^{38}$ Indeed, 1 Cor 9.20, supported by various statements in Romans 11, indicates in Watson's view a turning by Paul to the pagans only after the failure of this mission to the Jews. Watson appeals further to Paul's testimony that he received a Jewish lashing five times (cf. 2 Cor 11.24) as evidence of extensive contact with Jews in a missional setting, and many scholars have cited Paul's circumcision of Timothy in this relation, as reported by Acts 16.3. But I am not convinced by this case, for a number of reasons.

37 Paul's narratives of his call are not of course reducible to this strategy. In this relation see, more broadly, esp. the important accounts of George Lyons, Pauline Autobiography: Toward a New Understanding (Atlanta: Scholars, 1985); Beverly Gaventa, 'Conversion in the Letters of Paul', From Darkness to Light: Aspects of Conversion in the New Testament (Philadelphia: Fortress, 1986) 17-51; Alan Segal, Paul the Convert: The Apostolate and Apostasy of Saul the Pharisee (New Haven: Yale University, 1990); Donaldson, Paul and the Gentiles; in more general terms, Stark, The Rise of Christianity and my Deliverance of God, 125-66.

38 Paul, Judaism, and the Gentiles: A Sociological Approach (Cambridge: Cambridge University, 1986) 28-9. Note that this case is not apparent in the later revised edition subtitled Beyond the New Perspective (Grand Rapids: Eerdmans, 2007). 
We really have no idea when Paul received his synagogue lashings. These might fall into an early period of proclamation, but equally well might not. And even if these took place in an early period, we do not know exactly what gospel elicited them (cf. 1 Thess 2.14-16). Hence, although Watson's thesis is consistent with the lashings it is by no means necessitated by them.

More importantly, significant positive evidence stands against Watson's claims. All the references to Paul's call suggest that pagans were intrinsic to it, and this evidence cannot simply be dismissed. Galatians 1.15-16 are particularly clear, but the rest of the narrative in Galatians is consistently problematic for Watson as well. Paul tells us explicitly that his apostolic call and ministry were

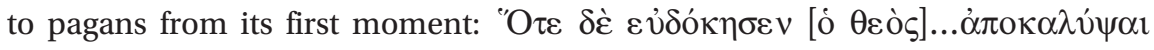

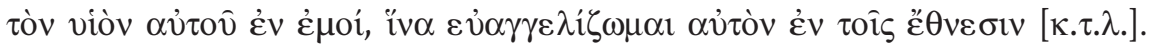
However, not all scholars advocating this view would necessarily follow Watson at this point, and they can soften the reading with the claim that Paul preached circumcision to Jews at times even as he was principally taken up with a mission to pagans; and this is the position of, among others, James D. G. Dunn. ${ }^{39}$

But this modified reading faces the obvious problem that Paul would have had no need to deny his occasional proclamations of Christ in tandem with circumcision to Jews in the Galatian setting, which explicitly concerns converts from paganism (cf. esp. Gal 4.8; 5.2). Indeed, to a charge couched in these terms in 5.11a Paul could have replied just as he does in 1 Cor 9.20. By 5.11 the letter to the Galatians has conceded the existence of a different gospel to Jews that includes circumcision (see 2.7-8), and just the same considerations apply to any invoking of the circumcision of Timothy, who had a Jewish mother (Acts 16.3). At bottom, Paul does not need to reject a charge concerning an orthopractic evangelism of Jews, and has already implicitly suggested as much. Hence, to cite 1 Cor 9.19-23 in this relation is not to explain the charge in Gal 5.11a so much as to problematize the text, which is clearly talking about something different. Paul's vociferous rebuttals of $5.11 \mathrm{a}$ in $5.11 \mathrm{~b}$ and $\mathrm{c}$ are now simply opaque. But this leads to a still more awkward point for this reading.

Paul states in 5.11a that at some point he 'proclaimed circumcision'. Ideally, in Dunn's construal, $\pi \varepsilon \rho \imath \tau \rho \mu \eta \dot{v}$ denotes the constituency to whom he was preaching in an accusative of respect or something grammatically analogous. But it seems highly unlikely that Paul is speaking of a constituency here on analogy to 2.8 (which actually uses a genitive); he is referring to the content of his apostolic proclamation, as the following refutations make clear. And it makes little sense to suggest that Paul is speaking here in some way of the need for Jews to become circumcised. This is simply absurd.

In short, this approach to the charge underlying the protasis in 5.11-in terms of an occasional mission by Paul to Jews-seems to collapse in all its variations 
into incoherence. That Paul had an occasional ministry to Jews is something that does not need to be denied (although that he ever had a sustained apostolic mission to Jews that preceded his mission to the pagans seems doubtful). But Paul is denying the content of 5.11a, and emphatically, so clearly we need a reading that can explain this. Only one option remains.

\subsection{A Post-call Mission to Pagans?}

A possibility sometimes noted but rarely advocated is a reference by Paul to an earlier phase in his apostolic ministry when he did in fact 'proclaim circumcision' (i.e., in the sense of expecting any male converts from paganism to adopt full Jewish law-observance). ${ }^{40}$ This implies further that Paul made an important transition at some point in his missionary praxis to a gospel that did not require circumcision of its converts from paganism, a shift that his present opponents clearly deplore but find rhetorically useful. ${ }^{41}$

This reading has been widely dismissed, but on grounds that turn out on closer examination to be quite fragile; in particular, they tend to beg the question. Moreover, a range of evidence, drawn both from the primary text and broader

40 Hübner (Law in Paul's Thought, 3 n. 18a) notes the advocacy of Carl Clemen (Die Chronologie der paulinischen Briefe aufs Neue untersucht [Halle: Max Niemeyer, 1893] esp. 51-2). Clemen's sensitivity to developmental possibilities allows him to incorporate a post-call construal of 5.11a smoothly into his overarching description of Paul. But Clemen places Galatians after Romans and arranges Paul's life in terms of two visits to Jerusalem, thereby generating a fascinating but dated broader description that need not detain us. Fung (The Epistle to the Galatians, 238) notes Edward Bosworth's general support for this view without citing Gal 5.11 ('The Influence of the Damascus Vision upon Paul's Theology', Bibliotheca Sacra 56 [1899] 278-300, esp. 298-9). Somewhat strangely, Bosworth combines a Lutheran understanding of Judaism and Paul's gospel with a developmental understanding of Paul's theology and mission at the point of proselytization. Paul himself leaves the law behind a few months after his conversion (293), but only rescinds it as a requirement for Gentile conversion after eight or ten years (289). Richardson (Israel in the Apostolic Church, 89) correctly notes the support for this view of D. W. Michaelis ('Judaistische Heidenchristen', ZNW 30 [1931] 83-9), who provides a brief, penetrating, and fairly assertive case. However, like Bosworth, Michaelis does not cite 5.11 explicitly. (I have been unable to find Eduard Meyer's [Ursprung und Anfänge des Christentum. Dritter Band: Die Apostelgeschichte und die Anfänge des Christentums (3 vols.; Stuttgart/Berlin: J. G. Cotta'sche, 1923)] attestation to this view as asserted by Schlier [Der Brief an die Galater, 238 n. 4]; Meyer's position seems traditionally Lutheran.) George Howard is something of a special case, treating 5.11 intelligently and carefully (cf. Paul: Crisis in Galatia [Cambridge: Cambridge University, 1979] esp. 8, 10, 39, 44, and notes) but essentially in dependence on a distinctive broader reconstruction of the opponents' gospel and activities. This reconstruction has not been widely followed; Martyn's Galatians is more up to date and plausible. Moreover, Howard's argument is problematic in basic methodological terms (see Barclay, 'Mirror Reading', n. 36 above), so it will not be considered in detail here.

41 It is this unexpected but highly significant biographical implication that has generated my detailed engagement with 5.11 here. 
church history, stands positively in the reading's favour. It seems then that the interpretative road less travelled turns out to be strangely workable. We will begin a more detailed advocacy by addressing past objections and their weaknesses.

There are two distinguishable types of protest, both of which reject the postcall reading on essentially a priori grounds. ${ }^{42}$ For some, it seems that the principal problem is simply one of inconsistency. ${ }^{43}$ Interpreters are offended by Paul 'flipflopping' on the basic question of circumcision. ${ }^{44}$ But for others, especially those influenced by loyalties to a particular construction of the Reformation, it is inconceivable that Paul could have undergone this sort of development given what we know from elsewhere of his basic theological convictions-in particular, of justification by faith.

(a) Theological inconsistency versus development. Inconsistency always creates rhetorical vulnerabilities in a contested situation. But it is still ubiquitous. Indeed, in a postmodern interpretative setting, the challenge is to find a text (or figure) that (or who) is not inconsistent in some significant sense. ${ }^{45}$ Church tradition is consequently thickly populated with what are more charitably called 'developmental' thinkers. Tertullian berated Montanism, and then converted to it. Augustine ridiculed predestinarian Manichaeanism for years, then campaigned

42 Another argument sometimes encountered at this point is the complaint that this activity is otherwise unattested in Paul. But while sometimes we need to consider the reasons for Paul's silences on other questions seriously, in this instance it counts for little; clearly Paul has every reason to avoid raising this issue himself. Moreover, there are arguably other pieces of corroborative evidence-one narrative in Paul, and a piece of evidence in Acts. However, space constraints dictate that these are analyzed elsewhere; see my Deliverance of God, 148-58, for a preliminary account; and my 'Antics at Antioch' (forthcoming) for more details.

43 And we have linked hands here with the tentative explanation forwarded earlier of the MSS variations.

44 Cf. i.a. Chrysostom-who goes on to provide a rather unconvincing defence: 'Since they were slandering him as one who constantly Judaized and was a hypocrite in his preaching, see how blamelessly he meets the challenge...' (cf. Mark J. Edwards, ed., Ancient Christian Commentary on Scripture: Galatians, Ephesians, Philippians [Downers Grove, IL: InterVarsity, 1999] 79, emphasis added); cf. also Margaret Mitchell's detailed and fascinating treatments in “"A Variable and Many-sorted Man”: John Chrysostom's Treatment of Pauline Inconsistency', Journal of Early Christian Studies 6 (1998) 93-111; 'Pauline Accommodation

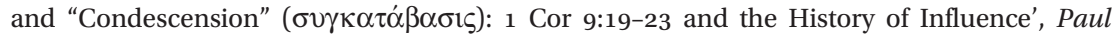
Beyond the Judaism/Hellenism Divide (ed. T. Engberg-Pedersen; London/Louisville, KY: Westminster John Knox, 2001) 197-214, 298-309; The Heavenly Trumpet: John Chrysostom and the Art of Pauline Interpretation (Louisville, KY: Westminster John Knox, 2002) 326-53, esp. 328.

45 This methodological insistence ought perhaps to be associated especially with Friedrich Nietzsche. Both his method (if it can be called this) and its drawbacks are articulated elegantly by Alasdair MacIntyre in Three Rival Versions of Moral Enquiry (Notre Dame: University of Notre Dame, 1990) esp. 32-57; and After Virtue (Notre Dame: University of Notre Dame, 3rd ed. 2007 [1981]) esp. 113-20. 
vigorously against Pelagius on behalf of predestination. A recent benchmark biography of Martin Luther has been written in three volumes corresponding to the three main developmental phases in his life (1483-1521, 1521-32, and 1532-46 CE) ${ }^{46}$ John Henry Newton converted to Christianity in 1748 but continued to work in the slave trade until 1754, only writing his famous denunciation of slavery, 'Thoughts upon the African Slave Trade', in 1788, forty years later. And so it goes on.

Consequently it is simply not compelling to claim that Paul could not have changed his mind or undergone a major transition. He may well have, like many famous Christians subsequently, at which point we should explore its implications and not (implausibly) deny its possibility. Indeed, to deny it is to beg the question concerning important possible evidence that he did change his mindthat he was a developmental thinker in this respect.

(b) Theological impossibility versus missiological development. Various postReformation interpreters have of course denied Paul's post-call gospel of lawobservance on apparently stronger grounds. But such denials are invariably based on what is known as 'the Lutheran reading' of Paul. ${ }^{47}$

The Lutheran reading is not so much a reading of Paul strictly in terms of Luther-although it has important points of contact with both Luther and subsequent Lutheran tradition-as a construal of his soteriology or 'gospel' in terms of a particular theory. The theory is well known and tends to be articulated in relation to what we might call Paul's justification texts where he deploys a set of interrelated motifs-works of law, judgment, justification, righteousness, faith, and the figure of Abraham. The 'Lutheran' theory understands Paul to be giving a universal account of conversion and salvation in these texts, describing how

46 Cf. Martin Brecht, Martin Luther: His Road to Reformation 1483-1521 (trans. James L. Schaaf; Philadelphia: Fortress, 1985 [1981]); Martin Luther: Shaping and Defining the Reformation 1521-1532 (trans. James L. Schaaf; Philadelphia: Fortress, 1990 [1986]); Martin Luther: The Preservation of the Church 1532-1546 (trans. James L. Schaaf; Philadelphia: Fortress, 1993 [1987]).

47 To use Krister Stendahl's famous phrase; see esp. 'The Apostle Paul and the Introspective Conscience of the West', HTR 56 (1963) 199-215; Paul among Jews and Gentiles, and Other Essays (Philadelphia: Fortress, 1976); and Final Account: Paul's Letter to the Romans (Fortress: Minneapolis, 1995). Classic accounts of this approach in soteriological terms include Philipp Melanchthon's commentary on Romans (Commentary on Romans [trans. F. Kramer; St Louis: Concordia, 1992]); and Calvin's brief articulation in book three of the Institutes, §§ 11-18 (Institutes of the Christian Religion [trans. F. Battles; Grand Rapids: Eerdmans, 1989] 2.36-129). For some more modern representatives see Seyoon Kim, The Origin of Paul's Gospel (Tübingen: J. C. B. Mohr [Paul Siebeck], 1981) and Paul and the New Perspective: Second Thoughts on the Origin of Paul's Gospel (Grand Rapids: Eerdmans, 2002); and Martin Hengel (with Roland Deines), The Pre-Christian Paul (trans. J. Bowden; London: SCM; Philadelphia: Trinity, 1991); and Hengel (with Anna Maria Schwemer), Paul between Damascus and Antioch: The Unknown Years (trans. J. Bowden; London: SCM, 1997). 
the generic convert (including himself) progresses from an agonized experience of condemnation under the law to a blessed experience of salvation and forgiveness through faith alone, an account consequently centered on the individual's introspective journey to salvation. So Paul's shift from Jewish persecutor of the church to Christian apostle must correlate exactly with the shift in the Lutheran theory from an agonized existence in relation to attempting works informed by the law to the blessedness of forgiveness in relation to Christ and faith alone. Paul, according to this theory, simply had to have left all works of law behind on the road to Damascus; he began his journey not knowing Christ but struggling unhappily and anxiously to fulfill the demands of the law, and ended it knowing both of Christ and of justification by faith alone, the demands of the law having been entirely abandoned. And herein lies the impossibility of a post-call reading of Gal 5.11a.

If an interpreter is already convinced on the basis of Paul's justification texts that the apostle's account of salvation is 'not through works of law but through faith alone' then it is essentially inconceivable that Paul would ever 'proclaim circumcision' as a Christian apostle. ${ }^{48}$ This would constitute a paradigmatic embarrassment. ${ }^{49}$ But clearly this is not actually a good reason for rejecting this reading of Gal 5.11a. Such a denial simply begs the (admittedly important) question.

The Lutheran construal of Paul's justification texts does not account for more than a small portion of his extant writings on salvation and is, moreover, deeply contested as the correct interpretation of those texts. ${ }^{50}$ Its cogency has

48 Cf. Charles J. Ellicott (Epistle to the Galatians, with a Revised Translation [New York: John Wiley, 1860] 125, emphasis original): 'a reference...for which there is not the slightest grounds...'; Burton: 'doubtless [a reference] to his pre-Christian life, since we have no information that he ever advocated circumcision after he became a Christian' (A Critical and Exegetical Commentary, 286); D. Hans Lietzmann: 'Wenn er noch die Beschneidung als Heilsgrundlage predigte...so würden ihn diese in Frieden lassen; dann wäre aber auch seine Predigt keine echte Christus-predigt' (An die Galater [Tübingen: Mohr Siebeck, 3rd ed. 1932] 38); Schlier: 'Erst recht ist daraus nicht zu folgern, dass er als Apostel vormals die Beschneidung gepredigt hat' (Der Brief an die Galater, 172 n. 2); Mussner: 'Der indikativische Präsenssatz...hat selbstverständlich irrealen Sinn...; der Apostel verkündet ja in Wirklichkeit die Beschneidung nicht' (Der Galaterbrief, 358 n. 106); Bruce: 'Not, we may be sure, since he was commissioned to be an apostle of Jesus Christ: the logic of the law-free-and therefore circumcision-free-gospel was implicit in his Damascus-road experience... [Indeed, the charge that he still preached circumcision is] preposterous' (The Epistle to the Galatians, 236); Hübner: '...one cannot infer from Gal 5.11 any initial Jewish-Christian preaching of the Law on Paul's part, for his conversion to Christianity led, more in his case than with others, to a breach with all legalism. Modern research on Paul, of course, regards this almost as an axiom. Thus Galatians is on a level with the Damascus experience' (Law in Paul's Thought, 3). Not a lot of actual reasoning or argument is discernible in these judgments.

49 Cf. Thomas Kuhn, The Structure of Scientific Revolutions (Chicago/London: University of Chicago, 3rd ed. 1996 [1962]).

50 Most notably by anyone advocating 'the new perspective'; see esp. the classic studies by Stendahl listed in n. 47 ('The Apostle Paul', Paul Among Jews and Gentiles, and Final 
been disputed by important scholars throughout the entire modern interpretative period, and mainstream Pauline scholarship has been significantly preoccupied with its debate for almost fifty years. Hence any denial of the postcall reference of Gal 5.11a in the name of the Lutheran construal of Paul's gospel is merely petitio principii. Read with a post-call reference, Gal 5.11a might be important evidence of the falsity of the Lutheran construal of Paul. And with this objection removed we can turn to some evidence that stands in favour of the reading.

The principal difficulty in the past with the post-call reading has of course been the supposed embarrassment caused by its inconsistency-that the apostle to the pagans who so famously advocated circumcision-free conversion included at some stage full Jewish law-observance in his missionary ethic. Hence the history of interpretation of this text, perhaps from its first scribal transmitters through to its recent historical critical interpreters, has largely been one of marginalization. But I suggest that this very embarrassment within the tradition attests to the probable truth of this reading.

It is precisely its embarrassment that delivers the reading's rhetorical force in the polemical Galatian situation, and that consequently explains both its presence in the argument and Paul's cryptic but powerful responses. Paul's opponents are, after all, trying to embarrass him (or worse). Its scandal is therefore actually one of its strengths. We know exactly why this charge has been made and this behaviour brought up! So we must now ask not so much whether the reading is too embarrassing to be entertained, as whether the further local data support this reading, and the missionary transition implicit in the embarrassment is plausible.

In fact, a reference by $5.11 \mathrm{a}$ to post-call, apostolic activity is suggested positively by Paul's language of proclamation in 5.11a that integrates most obviously with his widespread use of a diplomatic discourse to describe his apostolic work. ${ }^{51}$ It is clearly not implausible to suggest that Paul, in obedience to his divine commission, 'preached' or 'proclaimed' Christ to pagans-that is, acted as a Christian missionary. (He could do this whether the gospel's associated ethic was lawobservant or not.) So we know why the text is freighted with his own language;

Account); but also E. P. Sanders (Paul and Palestinian Judaism: A Comparison of Patterns of Religion [Philadelphia: Fortress, 1977] and Paul, the Law, and the Jewish People [Philadelphia: Fortress, 1983]); and Dunn (Jesus, Paul and the Law: Studies in Mark and Galatians [London: SPCK; Louisville, KY: Westminster John Knox, 1990]). This list could be greatly lengthened.

51 Watson is alert to the importance of this evidence (Paul, Judaism, and the Gentiles, 30); it is dismissed-rather unconvincingly-by Donaldson (Paul and the Gentiles, 366). As noted earlier (cf. esp. n. 34), these data are not definitive but are indicative. 
it refers to Paul and so, in a sense, his opponents are merely throwing his own position back at him. ${ }^{52}$

Moreover, we now know why Paul treats this issue in the anomalously concessive way that he does-that he is not 'still proclaiming circumcision'. He cannot reverse this activity narratively and rhetorically at his call because it was not reversed then; it was only reversed later on. The best he can do is to supply the compact set of inferences in $5.11 \mathrm{~b}-\mathrm{c}$ arguing that evidence abounds that he is not still doing this. ${ }^{53}$ Hence we have explained his repeated use of the word ع̌ $\tau$. Some broader-and rather fascinating-evidence drawn from church history further corroborates this reading.

While certain theological expectations have in the past led to an overly static treatment of Paul, and to the concomitant dismissal of evidence of his development as suggested by texts like Gal 5.11a, data drawn from historical missions suggest that Paul's missiological development is anything but exceptional. Significant shifts in missiological praxis are evident throughout the history of Christian mission-such shifts frequently getting their advocates into trouble with central headquarters just as Paul experienced. That is, missionaries made perceived concessions in their specific missionary locations to local culture, which involved simultaneously shifting away from the traditional Christian ethic practiced originally by the missionaries and still practiced elsewhere by the rest of the church. This disjunction then caused conflict when it became known back at the mission's headquarters in the home church and country/ies. These narratives are uncannily parallel to Paul's story of fully endorsing then shifting away from sacred Jewish practices and toward more indigenous pagan practices in certain respects, a shift that later had to be vigorously defended against offended Jewish Christian traditionalists. ${ }^{54}$

Two classic cases of this from later church history are Matteo Ricci in China in the late sixteenth century and Roberto de Nobili in India in the seventeenth, both of whom contextualized their Christian proclamations in astonishingly integrated ways, incurring the wrath of the Vatican in the process. ${ }^{55}$ But China remains the missionary context where these dynamics have been most visible-probably

52 Alternatively, they are utilizing an apostolic discourse common to the early church, as (i.a.)

1 Cor 15.1-11; and Gal 1.1, 6-7, 11-12, 17-20; 2.2, 6-9, suggest.

53 At this stage we have returned to a position close to Howard's (Paul: Crisis in Galatia).

54 Much more could be said at this point. Some initial soundings are supplied by my 'Antics at Antioch' (forthcoming).

55 Overviews in Paul Johnson, 'Almost-Chosen Peoples [1500-1910]', A History of Christianity (New York: Touchstone [Simon \& Schuster], 1976) 399-460; and Ruth A. Tucker, Jerusalem to Irian Jaya: A Biographical History of Christian Missions (Grand Rapids: Zondervan, rev. ed. 2004 [1983]) 67-70. More details are supplied for Ricci by Jonathan D. Spence (The Memory Palace of Matteo Ricci [New York: Viking Penguin, 1984]); and for de Nobili by Vincent Cronin (A Pearl To India: The Life of Roberto de Nobili [London: Hart-Davis, 1959]). 
because of its astonishingly rich indigenous culture that has repeatedly captivated missionaries. Indeed, a debate began in Ricci's day over ancestor veneration that continued for centuries known as 'the Chinese rites controversy'. ${ }^{56}$

Missionaries in China sensitive to Chinese culture often argued that traditional Chinese ancestor rites were merely an honouring of ancestors assisted by visual and practical prompts and so acceptable (cf. Exod 20.12) - a contextualized development in missionary praxis. But most Christian missionary movements viewed it in essentially Jewish terms as idolatry and false worship, and hence unacceptable, and so banned it. (Arguably the cause of Chinese missions was set back dramatically by this intransigent stance. ${ }^{57}$ ) But many other points of tension became apparent in subsequent missionary work in China.

Timothy Richard, a legendary Welsh Baptist missionary in the nineteenth century, got into difficulties with his employers for advocating famine relief in addition to preaching, aphoristic wall posters instead of street evangelism and tracts (which appealed to Chinese literary and poetic culture), and a full engagement with Buddhist literature by Christian scholars (and so on)-each of these a development, if not a shift in direction, from standard missionary policy that caused controversy and offence. ${ }^{58}$ But this missionary narrative is not confined to China. ${ }^{59}$

In the light of these scattered narratives of missiological development-which by no means exhaust the phenomenon-the shift in Paul's praxis denoted by Gal 5.11a from an ethic demanding the circumcision of male converts, probably along

56 The standard account is George Minamiki, The Chinese Rites Controversy from its Beginning to Modern Times (Chicago: Loyola University, 1985).

57 See esp. Lung-Kwong Lo, 'Identity Crisis Reflected in Romans 14:10-15:13 and the Implications for the Chinese Christians' Controversy on Ancestral Worship', Society of Biblical Literature 2002 Seminar Papers (Atlanta: Society of Biblical Literature, 2002) 1-32, 41. 58 See esp. the account of Andrew Walls, 'The Multiple Conversions of Timothy Richard: A Paradigm of Missionary Experience', The Gospel in the World: International Baptist Studies (ed. David Bebbington; Carlisle: Paternoster, 2002) 271-94; also Brian Stanley, The Bible and the Flag: Protestant Missions and British Imperialism in the Nineteenth and Twentieth Centuries (Trowbridge: Apollos, 1990) and The History of the Baptist Missionary Society, 1792-1992 (Edinburgh: T. \& T. Clark, 1992); and Lian Xi, The Conversion of Missionaries: Liberalism in American Protestant Missions in China, 1907-1932 (University Park: Pennsylvania State University, 1997). (My thanks to John Stenhouse and Grant A. Wacker for their assistance in this relation.)

59 Elisabeth Elliot documents an astonishing journey toward cultural accommodation in relation to the South American Indians who killed her husband, and whom she subsequently evangelized; cf. The Savage My Kinsman (with epilogues; Ventura, CA: Regal, 1996 [1961]). And I have received information from Grant Wacker concerning rumoured flexibility by a Pentecostal missionary in Africa in the 1930s toward polygamy. Apparently this figure asked single converts not to engage in polygamous marriages in the future but did not ask converts already in existing polygamous arrangements to dissolve them. (Private communications, July 6 and August 17, 2010.) 
with the observance of Jewish calendrical and dietary customs, to one abandoning such practices, seems unremarkable. Indeed, it appears to be a classic instance of contextualization by an intelligent and empathetic missionary at work on the ground within his designated constituency. Far from being unthinkable or impossible then, the narrative glimpsed by a post-call reading of Gal 5.11a is understandable if not commendable. This does not remove the story's negative value in a polemical situation; it remains embarrassing for Paul in Galatia that he shifted his praxis at some earlier point. But it is by no means impossible as the putative reference behind the text, while its very embarrassment is useful evidence in the reading's favour in its later polemical setting.

In short, it seems that the post-call construal of Gal 5.11a is superior to its strongest interpretative alternatives on all counts. There are no decisive objections to it, and much can be said directly in its support, all of which seems to suggest that its long interpretative marginalization should cease. And as a result of this we can conclude that Paul did spend part of his apostolic career proclaiming a gospel that included a commitment to circumcision, which is to say that he did not always relax this expectation for male converts to his movement from paganism. At some auspicious moment a significant transition in Paul's missionary praxis seems to have taken place from a gospel merely for the uncircumcised to one that allowed them to remain so following their conversion. But we must leave it to other studies to establish exactly when and where this transition took place, and to reconstruct its rationale. It suffices for now to conclude that Gal 5.11, suitably interpreted, points toward the fact that such a transition did take place. At an early point in his missionary career, and by his own admission, Paul the apostle preached a law-observant gospel, and his modern interpreters must learn to interpret him in a way that comprehends this intriguing transition, rather than ignores it. 